\title{
PERPUSTAKAAN KOLABORATIF (MAKERSPACE LIBRARY) DI BANJARBARU
}

\author{
Muhammad El'Arif Billah \\ Program Studi Teknik Arsitektur Fakultas Teknik Universitas Lambung Mangkurat \\ h1b113220@mhs.ulm.ac.id
}

\author{
Dila Nadya Andini \\ Program Studi Teknik Arsitektur Fakultas Teknik Universitas Lambung Mangkurat \\ dila.andini@ulm.ac.id
}

\begin{abstract}
ABSTRAK
Saat ini perpustakaan di Banjarbaru masih dianggap tidak lebih hanya sebuah tempat untuk membaca buku dan buku-buku yang adapun hanyalah koleksi buku lawas, hal ini menimbulkan stigma bahwa perpustakaan tidak berkembang sesuai dengan kebutuhan masyarakat yang sudah terlalu bergantung dengan digitalisasi dan teknologi. Inilah yang mendasari faktor kurangnya minat untuk berkunjung ke perpustakaan. Oleh sebab itu, perlu direncanakan sebuah perpustakaan sebagai wajah baru ruang publik yang dapat mewadahi aktivitas untuk saling berkolaborasi dan menawarkan nilai tambah berupa jaringan sosial (social network) bagi masyarakat Banjarbaru. Tujuan dari perancangan Perpustakaan Kolaboratif (Makerspace Library) di Banjarbaru adalah agar terciptanya sebuah image baru sebuah perpustakaan di Banjarbaru dengan penerapan fungsi baru sehingga terwadahinya aktifitas saling berkolaborasi antara pengguna perpustakaan dalam berbagai macam aspek ilmu pengetahuan dan skill dengan maksud saling memperoleh nilai tambah untuk perkembangan zaman.

Kata kunci: Banjarbaru, Makerspace, Perpustakaan, Kolaboratif
\end{abstract}

\section{ABSTRACT}

The library in Banjarbaru is still considered as nothing more than a place to read books and the books themselves are only old book collections, this creates a stigma that libraries do not develop according to the needs of people who are too dependent on digitalization and technology. This is the underlying reason why people lack interest in visiting the library. Therefore, it is necessary to develop a library as a new face of public space that can accommodate activities for collaboration and offer social networks for the Banjarbaru community. The purpose of designing a Collaborative Library (Makerspace Library) in Banjarbaru is to create an educated, accustomed to reading, and highly cultured community. Through the library, people can exchange information and knowledge.

Keywords: The Library, Makerspace, Banjarbaru city, Collaborative 


\section{PENDAHULUAN}

Perpustakaan yang berfungsi sebagai sebuah ruang publik sentral ilmu pengetahuan sekaligus berfungsi sebagai penyedia sarana kebutuhan untuk mencari berbagai sumber informasi dan ilmu pengetahuan. Perkembangan zaman yang pesat menuntut perkembangan akan teknologi informasi yang tidak terlepas peran perpustakaan sebagai faktor utama dalam pelestarian dan penyebaran informasi berbagai macam ilmu pengetahuan sebagai tempat rujukan bagi para pencari ilmu dan pengembangan karya.

Di era seperti ini seharusnya Perpustakaan tidak lagi dianggap sebagai ruang senyap, melainkan ruang untuk berekspresi yang terbuka bagi perkembangan kreativitas dan budaya knowledge sharing bagi masyarakatnya. Di era yang serba modern dan berkembang pesat seperti sekarang, semua orang membutuhkan informasi sebagai suatu hal yang mutlak. Tanpa adanya informasi atau ketinggalan informasi akan membuat seseorang tersisih dan terbelakang. Perpustakaan sudah sewajarnya dapat menyesuaikan dengan perkembangan teknologi dan perilaku pengguna di zaman modern ini agar tidak tertinggal. Perpustakaan sekarang ini sudah seharusnya dianggap sebagai learning organization sehingga seharusnya responsif dan terbuka terhadap teknologi, pengetahuan, lingkungan dan perkembangan zaman. Perpustakaan sudah seharusnya mengadopsi, mengembangkan, menyempurnakan pemikiran, sistem maupun teknik secara berkelanjutan untuk menghasilkan layanan informasi yang lebih efektif dan efisien (Stueart \& Moran, 2007).

Salah satu perkembangan dari inovasi layanan perpustakaan yang memfasilitasi kebutuhan para penggunanya dengan memanfaatkan kemajuan teknologi adalah makerspace. Asosiasi teknologi informasi pendidikan tinggi (Educause, 2013) menginterpretasikan sebuah makerspace sebagai tempat orang berkumpul untuk berbagi sumber daya dan pengetahuan, mengerjakan proyek, jaringan dan membangun ilmu pengetahuan yang baru. Sebuah makerspace menyediakan perlengkapan alat dan ruang berkerja (bengkel) di lingkungan perpustakaan. Makerspace terkadang disebut sebagai ruang hacker yang sering dikaitkan dengan bidang keahlian seperti teknik, ilmu komputer dan desain grafis. Makerspace menurut (Curry, 2017) adalah ruang di perpustakaan untuk para user dan maker untuk berinteraksi dan berkreasi.

Pada awalnya sebuah makerspace berada di tempat-tempat umum dan tidak disediakan di dalam perpustakaan, namun seiring perkembangan zaman yang semakin berkembang ke arah modern. Dalam kondisi ini sebuah makerspace telah dijadikan sebuah tren baru di dalam perpustakaan sebagai sarana pembelajaran di masyarakat. Dengan adanya makerspace di perpustakaan maka telah memperkuat posisinya sebagai ruang publik yang netral bagi setiap masyarakat.

Perpustakaan di Banjarbaru masih belum memiliki sebuah ruang publik seperti makerspace. Hal tersebut menyebabkan masyarakat pada akhirnya memilih tempat lain sebagai sebuah alternatif untuk mereka berkolaborasi, seperti kafe ataupun tempat-tempat semi private lainnya yang cenderung memberi syarat terhadap kemampuan finansial. Secara tidak langsung terciptalah pola atau gaya hidup baru yang lebih fleksibel di masyarakat. Dampaknya, image sebuah perpustakaan yang pada dasarnya adalah tempat dimana orang-orang saling beredukasi, sekarang hanya dipandang sebagai sebuah tempat yang terlalu formal dan tidak santai sehingga terasa enggan untuk dikunjungi.

Sesuai dengan maksud pendahuluan di atas, maka tujuan dari perancangan Perpustakaan Kolaboratif (Makerspace Library) di Banjarbaru adalah agar terciptanya sebuah image baru sebuah perpustakaan di Banjarbaru dengan penerapan fungsi baru sehingga terwadahinya aktifitas saling berkolaborasi antara pengguna perpustakaan dalam berbagai macam aspek ilmu pengetahuan 
dan skill dengan maksud saling memperoleh nilai tambah untuk perkembangan zaman.

\section{PERMASALAHAN}

Pada awalnya perpustakaan berperan penting dalam membantu pengguna mencari literasi, namun kini fungsi dari perpustakaan bertambah demi menyediakan fasilitas bagi pengguna untuk menjadi seorang kreator. Banyak perpustakaan yang menawarkan perpaduan antara akses fleksibel dalam menggunakan peralatan dan sumber daya untuk proyek individu dan kelompok serta program untuk mendorong pembelajaran, penemuan dan eksplorasi. Kota Banjarbaru tentu memiliki fasilitas ruang publik berupa perpustakaan dari berbagai macam instansi mulai dari perpustakaan umum hingga perpustakaan milik swasta lainnya namun hingga sekarang perkembangan perpustakaan di kota Banjarbaru sendiri masih tergolong tertinggal dibandingkan dengan perkembangan kebutuhan penggunanya sendiri, sehingga perpustakaan yang seperti apa sebenarnya masyarakat Banjarbaru butuhkan.

\section{TINJAUAN PUSTAKA}

Sulistyo Basuki dalam (Yahyono, 2007) menyebutkan bahwa perpustakaan adalah sebuah ruangan, bagian sebuah gedung yang digunakan untuk menyimpan koleksi buku dan terbitan lainnya yang disimpan menurut tata susunan yang terorganisir agar mudah digunakan oleh pembacanya untuk mencari literasi dan bukan sebuah koleksi untuk diperjual belikan.

Perpustakaan adalah suatu unit kerja yang dikelola suatu badan ataupun lembaga yang mengelola bahan pustaka, baik berupa koleksi buku-buku dan arsip-arsip yang mempunyai manfaat baca yang diatur secara sistematis dan terprogram menurut aturan standar penyusunan buku perpustakaan sehingga dapat digunakan sebagai sumber informasi oleh setiap pemakainya, Ibrahim Bafadal dalam (Yahyono, 2007).

Perpustakaan yang ditargetkan untuk masyarakat umum berlatar belakang oleh perkembangan inovasi layanan perpustakaan yang dapat memfasilitasi kebutuhan penggunanya dengan memanfaatkan perkembangan teknologi dan informasi.

dari Dari Sana apresiasi dan kontribusi diharapkan terhadap perkembangan perpustakaan sebagai sarana pendidikan alternatif (non formal), maka upaya untuk memaksimalkan peran dari perpustakaan sebagai media pendidikan alternatif semakin mudah untuk terwujud, dengan demikian perpustakaan dapat mengembangkan perannya lagi dari peran terbatas menjadi signifikan dan progresif.

\section{A. Definisi Makerspace}

(Tweney, 2009) "Makerspaces are places where like-minded persons gather to work on personal projects, share tools and expertise as well as learn from each other." Yang berarti makerspace adalah tempat dimana orang-orang dengan pemikiran yang berbeda-beda dengan satu tujuan yang sama berkumpul untuk mengerjakan sebuah produk dari hasil pemikiran mereka masing-masing, dengan dukungan berbagai macam peralatan dan keahlian yang dimiliki oleh masing-masing orang.

Singkatnya, makerspace merupakan sebuah keberlanjutan dari sebuah aktivitas yang mewadahi: co-working, hackerspace dan fab-lab.

\section{B. Analisis}

1. Analisis Pelaku dan Aktivitas

Dalam perancangan Perpustakaan Kolaboratif (Makerspace Library) di Banjarbaru, pelaku dapat dibedakan menjadi dua kategori, yaitu pengunjung (target user) dan pengelola. 


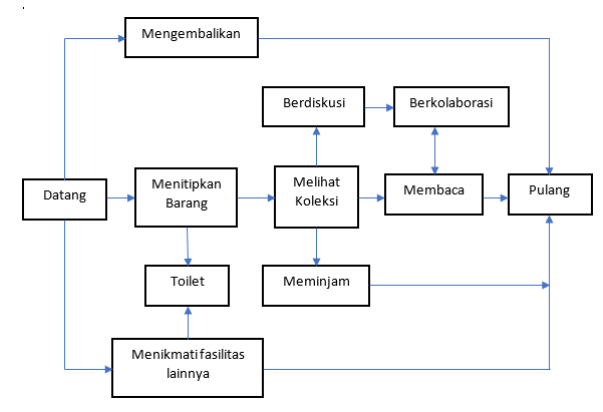

Gambar 1. Pola Aktivitas Pengunjung Sumber: Analisis Pribadi (2020)

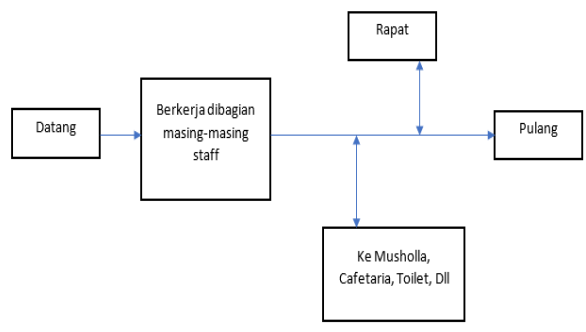

Gambar 2. Pola Aktivitas Pengelola Sumber: Analisis Pribadi (2020)

\section{Analisis Besaran Ruang}

Tabel 1. Kebutuhan Ruang Berdasarkan Analisis Pelaku dan Aktivitas

\begin{tabular}{|c|c|c|c|}
\hline $\begin{array}{c}\text { No } \\
\cdot\end{array}$ & $\begin{array}{c}\text { Kategori } \\
\text { Pelaku }\end{array}$ & Subjek & $\begin{array}{c}\text { Kategori } \\
\text { Kebutuhan } \\
\text { Ruang }^{*}\end{array}$ \\
\hline \multirow[t]{3}{*}{1} & \multirow[t]{3}{*}{$\begin{array}{l}\text { Pengunjun } \\
\mathrm{g}\end{array}$} & $\begin{array}{l}\text { Mahasiswa } \\
\text { - Arsitektur } \\
\text { - Pertanian } \\
\text { - Bahasa } \\
\text { - dll. }\end{array}$ & \multirow{3}{*}{$\begin{array}{ll}\text { - } & \text { Area masuk } \\
\text { - } & \text { Lobby } \\
\text { - } & \text { Perpustakaa } \\
& \mathrm{n} \\
\text { - } & \text { Makerspace } \\
& \text { area } \\
\text { - } & \text { Servis } \\
\text { - } & \text { Lansekap }\end{array}$} \\
\hline & & $\begin{array}{l}\text { Komunitas } \\
\text { - Fotografer } \\
\text { - Sendratasik } \\
\text { - Elektronik } \\
\text { - Sepeda } \\
\text { - Motor } \\
\text { - Gamers } \\
\text { - Sosialis } \\
\text { - Studi klub } \\
\text { - dll }\end{array}$ & \\
\hline & & $\begin{array}{l}\text { Masyarakat } \\
\text { umum }\end{array}$ & \\
\hline 2 & Pengelola & $\begin{array}{l}\text { - Kepala } \\
\text { perpustakaa } \\
\text { n }\end{array}$ & $\begin{array}{ll}\text { - } & \text { Area masuk } \\
\text { - } & \text { Lobby } \\
\text { - } & \text { Ruang } \\
& \text { admin }\end{array}$ \\
\hline
\end{tabular}

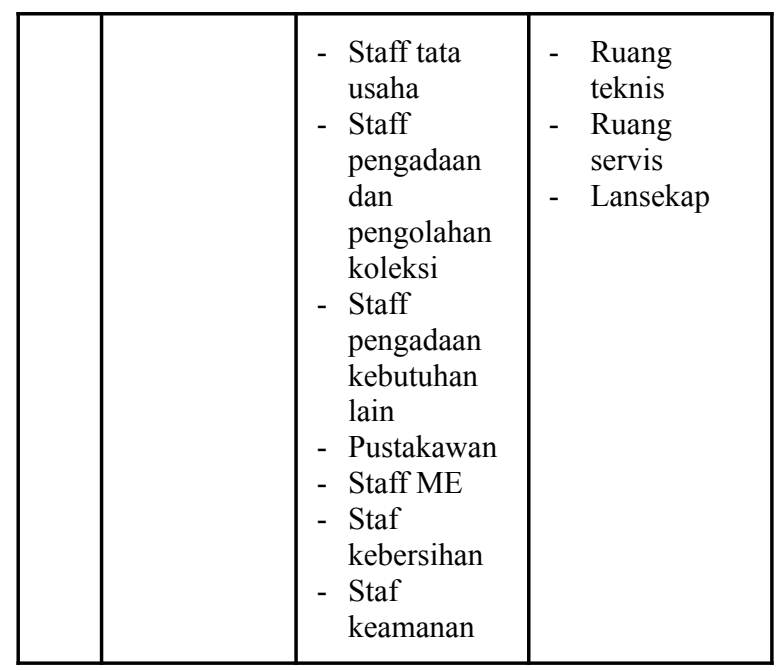

Sumber : Analisis Pribadi (2020)

Tabel 2. Penjabaran Kebutuhan Ruang Berdasarkan Pengelompokan Ruang

\begin{tabular}{|c|c|c|}
\hline $\begin{array}{c}\text { No } \\
\text {. }\end{array}$ & $\begin{array}{c}\text { Kategori } \\
\text { Ruang }\end{array}$ & Nama Ruang \\
\hline 1 & Area masuk & $\begin{array}{l}\text { - Main entrance } \\
\text { - Secondary entrance } \\
\text { - Service entrance }\end{array}$ \\
\hline 2 & Lobby & $\begin{array}{l}\text { - Lounge } \\
\text { - Ruang informasi dan } \\
\text { layanan } \\
\text { - Kafetaria } \\
\text { - Stationery } \\
\text { - Galeri/R. Pameran }\end{array}$ \\
\hline 3 & $\begin{array}{l}\text { Perpustakaa } \\
\mathrm{n}\end{array}$ & $\begin{array}{l}\text { - Ruang koleksi umum } \\
\text { - } \text { Ruang koleksi khusus } \\
\text { - Ruang baca } \\
\text { - } \text { Ruang audio visual } \\
\text { - } \text { Ruang komputer }\end{array}$ \\
\hline 4 & $\begin{array}{l}\text { Makerspace } \\
\text { area }\end{array}$ & $\begin{array}{l}\text { - Ruang diskusi } \\
\text { - Studio seni } \\
\text { - } \text { Studio digital } \\
\text { - Bengkel } \\
\text { - } \text { Ruang seminar }\end{array}$ \\
\hline 5 & $\begin{array}{l}\text { Ruang } \\
\text { admin }\end{array}$ & $\begin{array}{l}\text { - Ruang kepala perpustakaan } \\
\text { - Ruang staff tata usaha } \\
\text { - Ruang staff pengadaan } \\
\text { koleksi } \\
\text { - Ruang staff layanan } \\
\text { perpustakaan } \\
\text { - Ruang staff layanan } \\
\text { makerspace } \\
\text { - Gudang koleksi } \\
\text { - Ruang rapat } \\
\text { - Ruang arsip }\end{array}$ \\
\hline
\end{tabular}




\begin{tabular}{|c|c|c|}
\hline 6 & $\begin{array}{l}\text { Ruang } \\
\text { teknis }\end{array}$ & $\begin{array}{l}\text { - Ruang ME } \\
\text { - Ruang pompa air } \\
\text { - Ruang genset } \\
\text { - Ruang teknisi }\end{array}$ \\
\hline 7 & $\begin{array}{l}\text { Ruang } \\
\text { servis }\end{array}$ & $\begin{array}{l}\text { - Toilet pengunjung } \\
\text { - Toilet pengelola } \\
\text { - Janitor } \\
\text { - Gudang } \\
\text { - Ruang loker pengunjung } \\
\text { - Ruang loker staff } \\
\text { - Pantry staff } \\
\text { - Ruang server }\end{array}$ \\
\hline 8 & Lansekap & $\begin{array}{l}\text { - Pos keamanan } \\
\text { - Parkir roda empat } \\
\text { pengunjung } \\
\text { - Parkir roda dua } \\
\text { pengunjung } \\
\text { - Drop off pengunjung } \\
\text { - Parkir roda empat } \\
\text { pengelola } \\
\text { - Parkir roda dua pengelola } \\
\text { - Parkir Sepeda } \\
\text { - Drop off servis } \\
\text { - Taman }\end{array}$ \\
\hline
\end{tabular}

Sumber : Analisis Pribadi (2020)

\section{Organisasi Ruang}

Berikut struktur organisasi ruang untuk perancangan Perpustakaan Kolaboratif (Makerspace Library) di Banjarbaru:

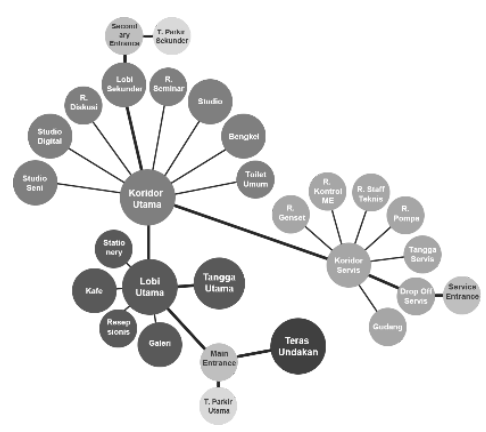

Gambar 3. Organisasi Ruang Lantai Satu Sumber : Analisis Pribadi, (2020)

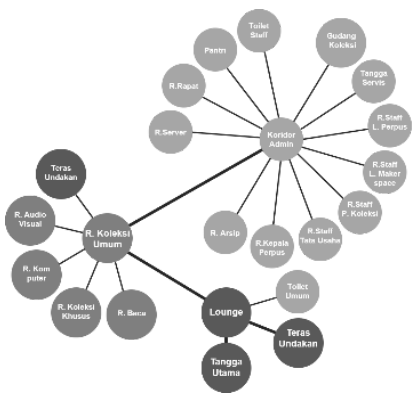

Gambar 4. Organisasi Ruang Lantai Dua

Sumber : Analisis Pribadi, (2020)

4. Analisis Bentuk Bangunan

Bentuk dasar bangunan merupakan massa dengan geometri konvensional yang digubah dengan menerapkan konsep teras berundak yang nantinya akan difungsikan sebagai area komunal semi-outdoor multi-fungsi. Area ini dapat dijadikan ruang diskusi, ruang baca, ruang seminar, ruang komunitas, rekreasi, dll. Sehingga, dapat memaksimalkan fungsi makerspace sekaligus menarik perhatian pengunjung dengan memberikan pengalaman yang berkesan.

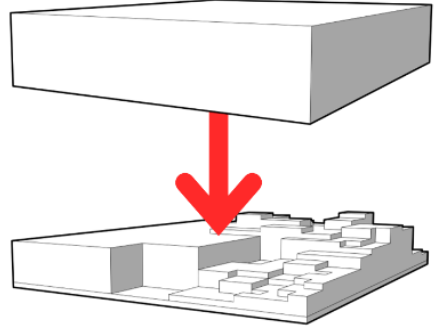

\section{Gambar 5. Eksplorasi Bentuk Bangunan Sumber : Analisis Pribadi, (2020)}

5. Analisis Struktur

Berdasarkan hasil analisis bentuk, jenis struktur yang akan digunakan dalam perancangan Perpustakaan Kolaboratif (Makerspace Library) di Banjarbaru ini adalah struktur rangka kaku.

Struktur rangka kaku terdiri dari komposisi kolom-kolom dan balok-balok. Kolom sebagai unsur vertikal yang fungsinya sebagai penyalur beban dan gaya menuju tanah keras, sedangkan balok adalah unsur horizontal yang fungsinya sebagai penunjang dan media yang membagi beban dan gaya ke kolom. Kedua unsur ini harus memiliki ketahanan terhadap tekuk dan lentur. 


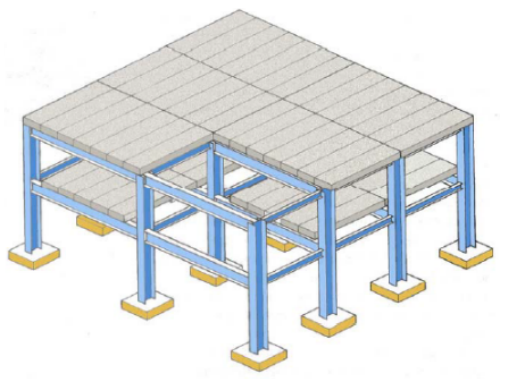

Gambar 6. Tipikal Struktur Gedung Berlantai Banyak

Sumber: Ariestadi, (2008)

\section{METODOLOGI}

Untuk memenuhi fungsi dari sebuah perpustakaan maka diperlukannya sumber daya berupa bangunan gedung, koleksi fisik perpustakaan, pengguna perpustakaan dan pustakawan. Faktor penting yang menunjang keberhasilan suatu perpustakaan adalah desain gedung dan desain interior perpustakaan, karena di dalam gedung tersebut segala Aktivitas di perpustakaan dilakukan. Perlu juga diperhatikan faktor kenyamanan dan keamanan dalam perpustakaan, seperti kebutuhan pengguna, tata ruang dan lingkungan yang baik di dalam perpustakaan.

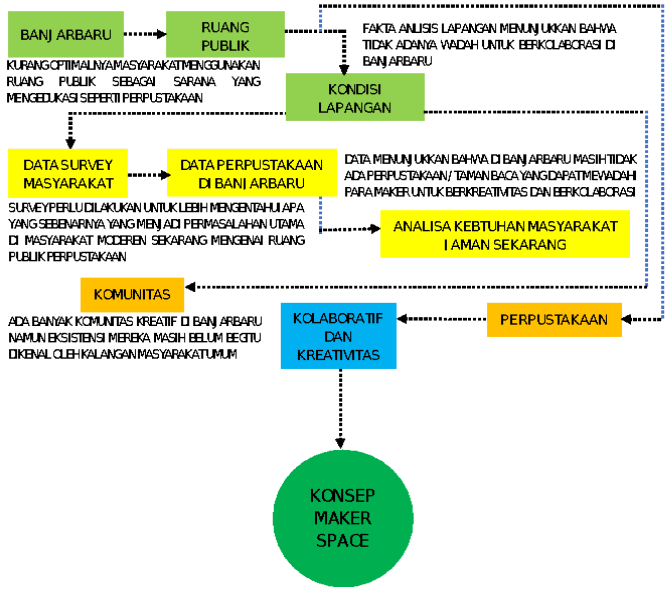

Gambar 7. Diagram Alur pikir Sumber : Analisis Pribadi, (2020)
Berdasarkan metode pendekatan desain di atas, maka strategi perancangan Makerspace Library di Banjarbaru dengan konsep dasar perancangan berdasarkan analisis:

\section{Analisis Fungsi}

Langkah perancangan yang bertujuan untuk mengetahui seperti apa saja kegiatan yang nantinya akan diwadahi di dalam perancangan. dengan diketahuinya macam kegiatan apa saja yang sudah ditentukan, maka di dalam perancangan nanti dapat menentukan siapa saja para pengguna didalam area makerspace nantinya.

\section{Analisis Ruang}

Mengelompokan ruang-ruang yang terkait berdasarkan kebutuhan fungsi ruang yang telah ditentukan sebelumnya bertujuan untuk mengakomodasi berbagai macam kegiatan yang terdiri dari standar-standar ruang dan pemrograman ruang.

\section{Penzoningan}

Penzoningan bertujuan untuk membagi wilayah ruang berdasarkan fungsinya seperti zona private, semi publik, publik, dan servis. Hal ini bertujuan untuk mengatur tatanan massa dan ruang sesuai kondisi tapak, juga berfungsi untuk mengatur sirkulasi ruang dalam dan ruang luar serta tatanan pola landscape.

\section{Analisis Bentukan Massa}

Analisis bentukan massa memiliki kejelasan konstruksi dan ruang yang menyatu antara ruang ke ruang seperti interior, eksterior, dan landscape.

5. Tatanan Ruang Dalam

Tatanan ruang dalam ditujukan untuk mengetahui rencana tatanan ruang yang dibutuhkan pada massa bangunan berupa gambaran denah ruangan. 
6. Analisis Utilitas

Analisis utilitas bertujuan untuk memberikan gambaran tentang sistem utilitas yang digunakan pada perancangan bangunan meliputi sistem air bersih dan kotor, drainase, pencahayaan, penghawaan, jaringan listrik, jaringan komunikasi, keamanan, dan sebagainya yang dibutuhkan di dalam perancangan tersebut.

\section{Analisis Fasad}

Analisis fasad dilakukan mengikuti konsep yang sudah ditetapkan dengan berbagai macam pertimbangan kegiatan dan fungsi yang sedang berlangsung yang nantinya akan menjadi dasar bentukan bangunan.

\section{PEMBAHASAN}

\section{A. Lokasi dan Deliniasi}

Lokasi tapak yang terpilih berada di JI. A. Yani KM. 35, Kota Banjarbaru. Penetapan lokasi tersebut sudah sesuai dengan pedoman kriteria pemilihan tapak, yaitu sebagai berikut:

Lokasi site berada di dalam kota dan dekat dengan infrastruktur kota sehingga cocok dengan standar SNP-PUPK tahun 2011 tentang pemilihan lokasi perpustakaan.

Ketersediaan

infrastruktur-infrastruktur penunjang mulai dari jalan, jaringan listrik, jaringan air bersih, dan saluran pembuangan air kotor.

- $\quad$ Lokasi yang ditentukan terletak pada kawasan yang strategis dengan jalan akses menuju lokasi yang mudah dicapai, yaitu jalan A. Yani.

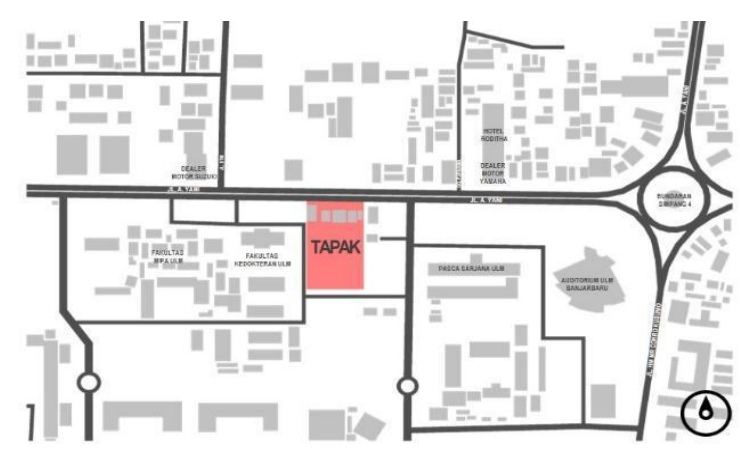

Gambar 8. Peta Lokasi Tapak

Sumber : Analisis Penulis, (2020)

\section{B. Konsep Program}

Perkembangan teknologi dan informasi yang tercermin dari perilaku pengguna millennial menuntut sebuah perpustakaan untuk mengembangkan lagi inovasi layanannya, salah satunya adalah penerapan konsep perpustakaan kolaboratif (makerspace library). Dalam menerapkan layanan perpustakaan kolaboratif hal yang perlu diperhatikan adalah survei kebutuhan dari penggunanya (user). Peran serta struktur pengorganisasian dari perpustakaan juga harus disesuaikan dengan misi institusi atau organisasi. Perpustakaan juga menganalisis berbagai macam materi digital maupun fisik yang akan dipergunakan di dalam layanan perpustakaan kolaboratif, memahami persyaratan hukum, teknis layanan serta peralatan, infrastruktur dan jenis layanan.

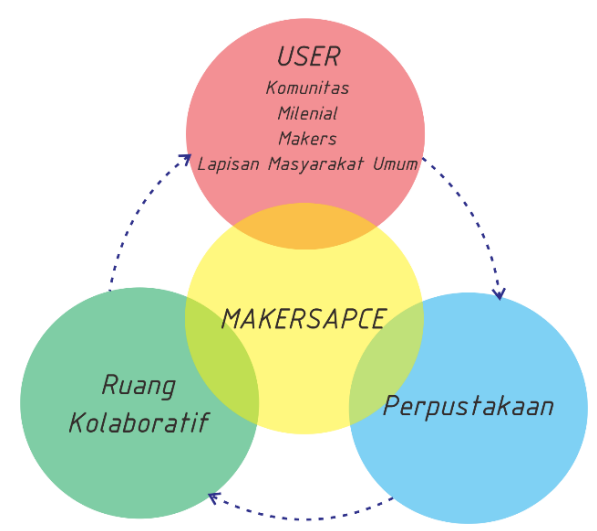

Gambar 9. Konsep Program Makerspace Library di Banjarbaru

Sumber : Analisis Pribadi, (2020)

Ari Samadhi dalam materi Teaching Improvement Workshop Batch tahun 2009 menggambarkan sebuah grafik segitiga efektivitas model pembelajaran. Pada gambaran tersebut menunjukkan dua kelompok model pembelajaran yaitu pembelajaran dengan metode secara pasif dan pembelajaran dengan metode aktif. 


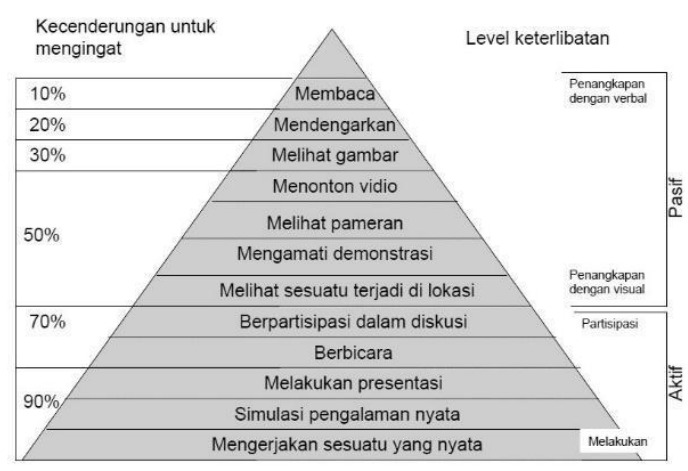

Gambar 10. Segitiga Efektivitas Model Pembelajaran

Sumber: Samadhi, (2009)

Dapat kita pahami melalui gambaran tersebut bahwa penangkapan materi seseorang secara verbal seperti (membaca, mendengarkan, melihat gambar) masih belum dikatakan efektif untuk sebuah metode pembelajaran seseorang. Sedangkan melalui sebuah penjelasan secara visual seperti (menonton video, melihat pameran, mengamati demonstrasi dan melihat sesuatu yang terjadi di lokasi) kecenderungan mengingat seseorang terbilang sudah efektif dengan metode yang seperti ini.

Dari semua permasalahan dan latar belakang yang sudah dibahas sebelumnya, dalam memadukan sebuah ruang publik yang ideal untuk masyarakat Banjarbaru, penerapan konsep perpustakaan kolaboratif akan diimplikasikan ke dalam sebuah perpustakaan sebagai respon terhadap perkembangan zaman yang semakin bergerak maju dan fleksibel. Melalui sebuah konsep kolaboratif di perpustakaan, tentunya akan menarik perhatian masyarakat sekitar. Perpustakaan dapat menyediakan ruang/tempat dan fasilitas pendukung lainnya sepeti kombinasi dari co-working space, workshop, machine shop dan studio. Sehingga, memungkinkan untuk seorang hacker dan desainer berbagi pengetahuan dan membangun sebuah produk kreatif dan inovatif.

\section{Konsep Perancangan}

Konsep programing ruang dari sebuah perancangan Perpustakaan Kolaboratif (Makerspace Library) di Banjarbaru ini adalah memadukan kedua fungsi ruang yang sebelumnya tidak ada dalam layanan perpustakaan di Banjarbaru, yaitu konfigurasi dari peruntukan sebuah ruang baca dan berkumpul di dalam perpustakaan dan sebuah konfigurasi dari peruntukan bengkel

kolaborasi.

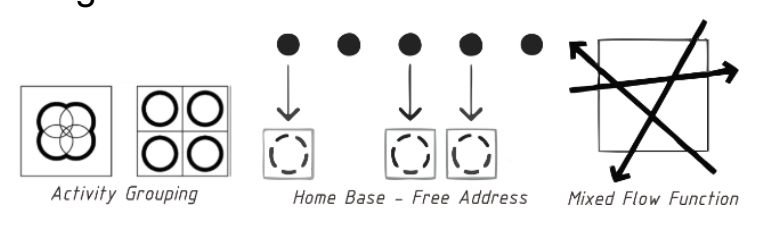

Gambar 11. Konsep Programing Ruang Sumber: (Peña \& Parshall, 2001)

Activity grouping: dimana user bebas untuk bergabung dengan segala macam aktivitas di dalamnya.

Home base is free address: semua user bebas untuk menentukan tempat mereka duduk untuk berkolaborasi dengan siapapun.

- $\quad$ Mixed flow function: sebuah titik temu dimana terjadinya interaksi antara semua user di dalamnya, dengan adanya pencapaian sebuah ruang multi direction seperti lobby atau aula pameran.

\section{Konsep Suasana Ruang}

Suasana ruang yang ingin dicapai dalam perancangan ini adalah suasana ruang yang nyaman, akrab dan dapat memacu kreativitas dengan penambahan fasilitas ruang belajar untuk kelompok grup maupun individu.
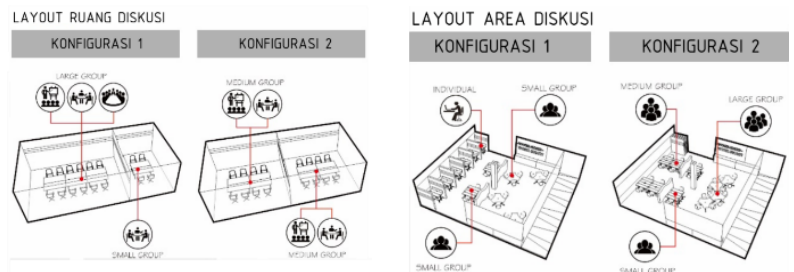

Gambar 12. Konsep Layout Ruang Sumber: Analisis Pribadi (2020) 
Gaya desain yang diterapkan adalah gaya desain kontemporer modern yaitu dengan mengemukakan desain yang lebih menegaskan dari segi kenyamanan tetapi juga 'kekinian'. Karakter desain muncul pada penggunaan material lantai dan dinding, yaitu memadukan antara parket dengan tegel dan pada dinding menggunakan material bata ekspos, sehingga memberikan kesan kolaboratif dan dinamis.

\section{E. Konsep Perancangan Interior}

Pada area perpustakaan terdapat fasilitas area untuk berkolaborasi yang menunjang para pengguna perpustakaan dan makers untuk tidak hanya bekerja dan berdiam di satu tempat, tetapi mereka juga dapat berpindah ke tempat lainnya untuk melepas penat agar tidak mudah bosan dan jenuh. Disini terdapat area coffee shop sehingga atmosphere terasa lebih fleksibel, dimana pengguna dapat menggunakannya untuk duduk bersantai sambil bekerja, ditujukan agar pengguna tidak mudah jenuh. Selain itu juga terdapat area gathering di tengah dengan fasilitas area duduk yang memungkinkan pengguna untuk saling berhadap-hadapan untuk melakukan diskusi kecil. Area ini dapat dikatakan sebagai meeting area yang santai. Terdapat banyak bukaan jendela, sehingga pencahayaan alami sinar matahari dapat masuk melalui jendela.
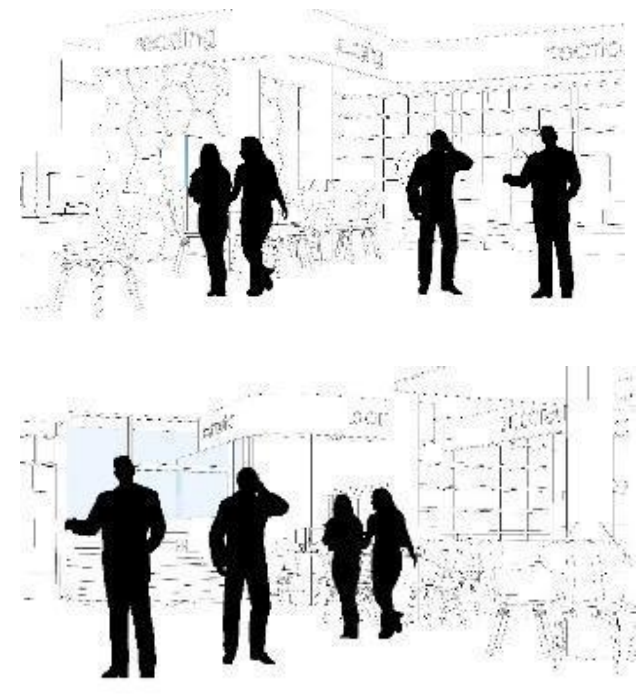

Gambar 13. Area Kolaborasi Sumber: Analisis Pribadi (2020)

HASIL
Perpustakaan sebagai institut
fundamental yang berbasis ilmu
pengetahuan tidak terlepas dari fungsinya
untuk menyediakan sarana dan prasarana
informasi dalam berbagai aspek ilmu
pengetahuan. Di era seperti ini,
perpustakaan sudah seharusnya tidak lagi
dipandang sebagai sebuah ruang senyap,
melainkan ruang untuk berekspresi yang
terbuka bagi perkembangan kreativitas dan
budaya knowledge sharing. Salah satu
perkembangan inovasi layanan
perpustakaan yang memberikan fasilitas
kebutuhan pengguna dengan memanfaatkan
kemajuan teknologi adalah makerspace.

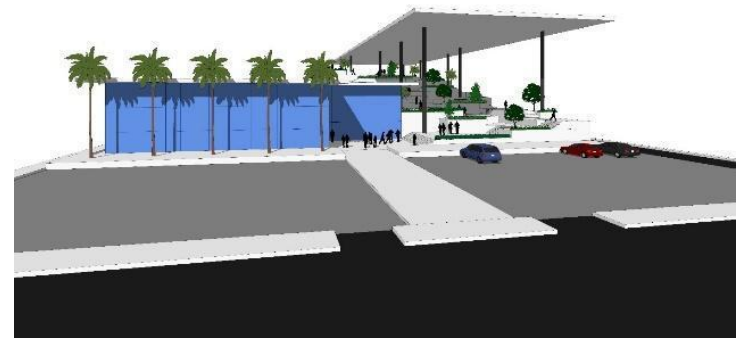

Gambar 14. Gagasan Ide Awal Sumber: Analisis Pribadi (2020) 


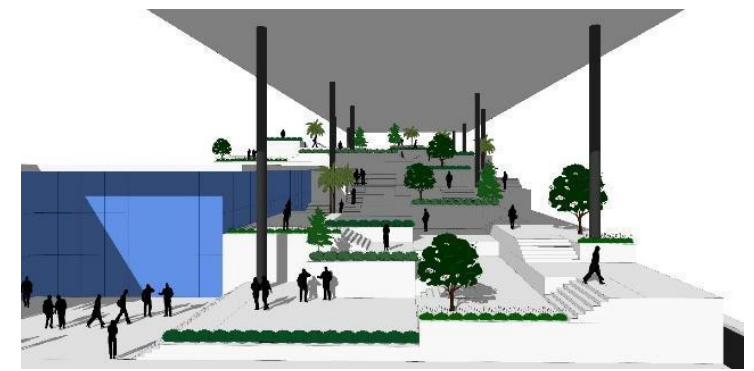

Gambar 15. Gagasan Ide Awal

Sumber: Analisis Pribadi (2020)

\section{KESIMPULAN}

Permasalahan yang diangkat adalah bagaimana rancangan sebuah perpustakaan di Banjarbaru sebagai wajah baru ruang publik yang dapat mewadahi aktivitas untuk saling berkolaborasi dan menawarkan nilai tambah berupa jaringan sosial (social network) bagi masyarakat Banjarbaru.

Dalam kondisi seperti ini sebuah makerspace telah menjadi sebuah tren baru di perpustakaan yang sewajarnya menjadi sarana pembelajaran di masyarakat. Dengan adanya makerspace perpustakaan telah memperkuat posisinya sebagai ruang publik yang netral bagi setiap golongan masyarakat.

Dari pembahasan latar belakang dan permasalahan yang telah dibahas sebelumnya, dalam memadukan sebuah ruang publik yang ideal untuk masyarakat Banjarbaru, penerapan konsep perpustakaan kolaboratif akan diimplikasikan ke dalam sebuah perpustakaan sebagai respon terhadap perkembangan zaman yang semakin bergerak maju dan fleksibel. Melalui sebuah konsep kolaboratif di perpustakaan, tentunya akan menarik perhatian masyarakat sekitar. Perpustakaan dapat menyediakan ruang/tempat dan fasilitas pendukung lainnya sepeti kombinasi dari co-working space, workshop, makerspace dan studio. Sehingga, memungkinkan untuk seorang hacker, desainer dan masyarakat biasa dapat berbagi pengetahuan dan membangun sebuah produk kreatif dan inovatif.

\section{DAFTAR PUSTAKA}

\section{Referensi Buku dan Jurnal}

Wijaya, S. J., Sitindjak, R. H., \& Suryanata, L. (2017). Implementasi Konsep Dynamic Pada Interior Creative Industry Co- working Space di Surabaya. JURNAL INTRA Vol. 5, No. 2, 746.

Adler, D. (1999). METRIC HANDBOOK Planning and Design Data. Oxford: Architectural

Press.

Ariestadi, D. (2008). Teknik Struktur

Bangunan Jilid 2. Jakarta: Direktorat

Pembinaan Sekolah Menengah Kejuruan.

Badan Pusat Statistik Kota Banjarbaru. (2020).

Kota Banjarbaru dalam Angka 2020.

Banjarbaru: BPS Kota Banjarbaru.

Ching, F. D.-K. (2008). Arsitektur: Bentuk, Ruang dan Tatanan (Edisi Ketiga). Jakarta:

Erlangga.

Colegrove, P. T. (2013). Editorial Board Thoughts: Libraries as Makerspace? Information Technology and Libraries, 3.

Curry, R. (2017). Makerspaces: A Beneficial New Service for Academic Libraries? Inggris:

Oxford Brookes University.

Educause. (2013). 7 Things You Should Know About Makerspaces. Educause Learning Initiative.

Lawson, F. R. (2000). Congress, Convention and Exhibition Facilities: Planning, Design and Management. Oxford: Architectural Press.

Leforestier, A. (2009). The Co-working Space Concept. Ahmedabad: CINE Term Project.

Neufert, E. (1996). Data Arsitek Jilid 1. Jakarta: Erlangga.

Neufert, E. (2002). Data Arsitek Jilid 2. Jakarta: Erlangga. 
Peña, W. M., \& Parshall, S. A. (2001). Problem Seeking: An Architectural Programming Primer. New York: John Wiley \& Sons, Inc.

Samadhi, A. (2009). Pembelajaran Aktif (Active Learning). Jakarta: Teaching Improvement Workshop, Engineering Education Development Project.

Stueart, R. D., \& Moran, B. B. (2007). Library \& Information Center Management Seventh

Edition. United States: Libraries Unlimited.

Suharyoto. (2014). Mengenal dan Mengelola Perpustakaan. Yogyakarta: Naafi' Book Media.

Sulistyo, B. (1991). Pengantar IImu

Perpustakaan. Jakarta: Gramedia Pustaka Utama.

Supriyanto, W., \& Muhsin, A. (2008). Teknologi Informasi Perpustakaan. Yogyakarta:

Kanisius.

Sutarno N.S. (2006). Manajemen Perpustakaan: Suatu Pendekatan Praktik. Jakarta:

Sagung Seto.

Syihabuddin Qalyubi, dkk. (2007). Dasar-Dasar IImu Perpustakaan dan Informasi. Yogyakarta: Jurusan Ilmu Perpustakaan dan Informasi Universitas Fakultas Adap UIN Sunan Kalijaga Yogyakarta.

Yahyono, Y. (2007). Efektivitas Koleksi Perpustakaan Nasional RI Terhadap Layanan Pengguna Jasa Perpustakaan. Jakarta:

Perpustakaan Nasional.

\section{Website}

Tweney, D. (2009, Maret 29). DIY Freaks Flock to 'Hackerspaces' Worldwide. Diambil kembali dari Wired:

https://www.wired.com/2009/03/hackes paces/ 